Article

\title{
Resting Energy Expenditure and Protein Balance in People with Epidermolysis Bullosa
}

\author{
Ana Paula Zidorio ${ }^{1, *}$, Camille Togo ${ }^{1}$, Rosie Jones ${ }^{2}$, Eliane Dutra ${ }^{1}$ and Kenia de Carvalho ${ }^{1}$ (D) \\ 1 Graduate Program in Human Nutrition, Faculty of Health Science, University of Brasilia, \\ Campus Universitário Darcy Ribeiro; Brasília 70910-900, Brazil; camillecristogo@gmail.com (C.T.); \\ eliane.unb@gmail.com (E.D.); kenia@unb.br (K.d.C.) \\ 2 Department of Dietetics, Birmingham Children's Hospital, Birmingham B4 6NH, UK; rosiejones1@nhs.net \\ * Correspondence: anacaio@unb.br; Tel.: +55-61-98114-2179
}

Received: 23 April 2019; Accepted: 29 May 2019; Published: 3 June 2019

\begin{abstract}
Epidermolysis bullosa (EB) is a group of conditions characterized by severe fragility of the skin that causes recurring blistering. The recessive dystrophic subtype of EB (RDEB) has a strong impact on the nutritional status. We evaluated the resting energy expenditure (REE) and presence of protein catabolism in patients with RDEB. REE was assessed in 10 subjects ( 7 females; age range 4-33 years) by indirect calorimetry and using a predictive equation. Nitrogen balance was calculated by protein intake and $24 \mathrm{~h}$ urinary urea excretion estimations. An assessment of body surface area (BSA) with infected and non-infected skin lesions was applied to the nitrogen balance burn equation that was adapted to EB. The REE values predicted by the equation were consistently lower than the ones measured, except for two subjects. All subjects recorded high protein and energy intake, with protein intake being higher than $4 \mathrm{~g}$ protein $/ \mathrm{kg} /$ day for five subjects. Even so, protein catabolism was observed in six subjects, three of whom had infected wounds. This study raises the hypothesis that the clinical and nutritional risks of people with RDEB are associated with an increased REE and negative nitrogen balance, which reinforces the importance of nutritional support.
\end{abstract}

Keywords: epidermolysis bullosa; nutrition; energy expenditure; nitrogen balance; catabolism

\section{Introduction}

Epidermolysis bullosa (EB) is a rare group of diseases characterized by skin fragility due to mutations in several structural proteins, which causes the repeated development of blisters [1-3]. EB subtypes are classified into four major groups, including EB simplex (EBS), Junctional EB (JEB), Dystrophic EB (DEB) with dominant (DDEB) or recessive (RDEB) types, and Kindler syndrome (1).

RDEB is one of the most severe types of EB that affect the nutritional status [4,5]. People with RDEB have a limited ingestion and possibly absorption of nutrients [6]. Nutritional needs are increased when there is blistering because of the loss of body fluids rich in minerals and proteins as well as the requirements associated with wound healing and infection fighting. Additionally, any damage to the skin removes the external protective barrier, which permits the dissipation of heat and water. Subsequently, this increases the energy requirements for maintaining normal body temperature. The association of factors that limit the intake and absorption of nutrients with those that increase nutritional needs can lead to anaemia, decreased immunocompetence, poor wound healing, increased risk of infection, and malnutrition [4]. The clinical and metabolic conditions of EB have been compared to those post-burn because of the presence of open skin lesions, increased infection risk, heat loss, increased protein turnover, and high energy expenditure [6-8]. Gamelli [9] was the pioneer in associating the hemodynamic response observed post-burn with the conditions present in EB. In burn sufferers, the relationship of the proportion of burned surface area with resting energy expenditure 
(REE) and protein catabolism is well known [10-13]. In the case of people with EB, REE appears to increase proportionally to the body surface area with blister involvement [7], and the supply of dietary energy and protein must be high in order to reduce catabolism and promote growth $[4,7,14,15]$.

Until now, there has been scarce information available about energy expenditure and protein catabolism in EB, with the majority based mainly on clinical practice and the use of predictive equations $[4,14,16]$. Only one case study performed indirect calorimetry in three children with JEB and RDEB [8], and, in another study [17], REE was measured by indirect calorimetry in an adult. No studies with nitrogen balance evaluation in people with EB were identified. The aim of this study was to investigate the measured and predictive REE and the presence of catabolism in subjects with RDEB. This study tested the hypothesis that people with RDEB experience protein catabolism. The predictive REE underestimated the measured REE and, therefore, it was not accurate in determining the nutritional requirements.

\section{Materials and Methods}

\subsection{Type of Study and Subjects}

A cross-sectional study focused on 10 subjects with RDEB who were attending the Nutrition Outpatient Clinic at the Brasilia University Hospital. The determination of the EB type was based upon clinical findings and electron microscopy of a skin biopsy sample. Subjects at least 4 years of age were included regardless of the extent of skin wounds. Patients under 4 years of age were excluded because of the constraints required during indirect calorimetry, and those with proteinuria were excluded because of possible errors in nitrogen balance results.

The Human Research Ethics Committee of Health Sciences Faculty of the University of Brasília (protocol n. 1674735) approved this study. Signed informed consent and assent, when appropriate, were obtained from all subjects. Figure 1 describes the sample process and procedures involved in the study.

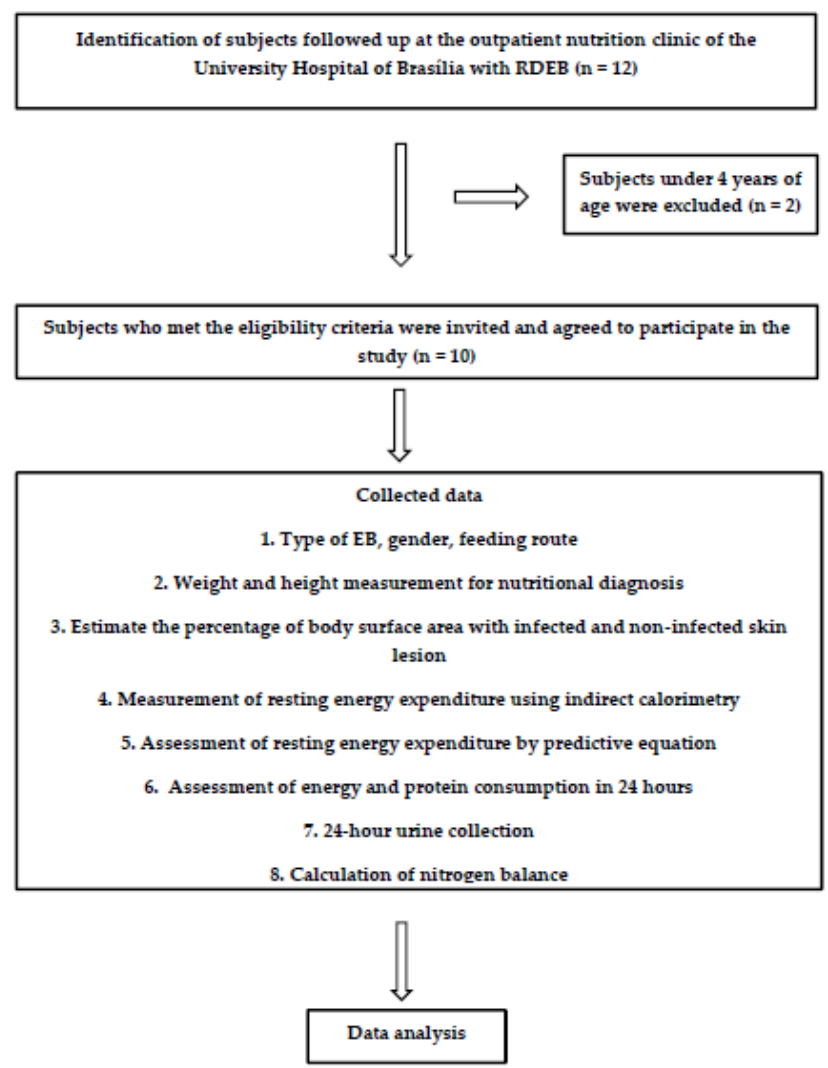

Figure 1. Study procedures. EB: epidermolysis bullosa, RDEB: recessive dystrophic EB. 


\subsection{Nutritional Status}

The nutritional status was evaluated on the basis of anthropometric data. Because of the fragility of the subjects' skin, the anthropometry measurements included weight and height measurements without the use of instruments that compressed the skin. The subjects wore light clothing and were barefoot for the anthropometric evaluation. The height/age index (H/A) was evaluated using the percentile $(p)$ proposed by the World Health Organization (WHO) [18] according to gender. The body mass index (BMI) was calculated to determine the nutritional status according to age [18-20].

\subsection{Estimation of Percentage of Infected and Non-Infected Skin Lesions of Body Surface Area (BSA)}

Estimates of the percentage of BSA (\% BSA) lesions were based on the EB Clinical Practice Guidelines for Nutrition Support [14]. This form contains a representative image of a person from back and front that is subdivided into 100 small rectangles, each representing $1 \%$ of the body surface (Figure 2). The subjects or caregivers were instructed to color the areas either yellow or pink to represent those with infected or non-infected skin lesions, respectively. The calculation of \% BSA wounded and infected was based on the sum of the areas shaded yellow or pink. Form filling was performed at the time of dressing change on the eve of the indirect calorimetry test.
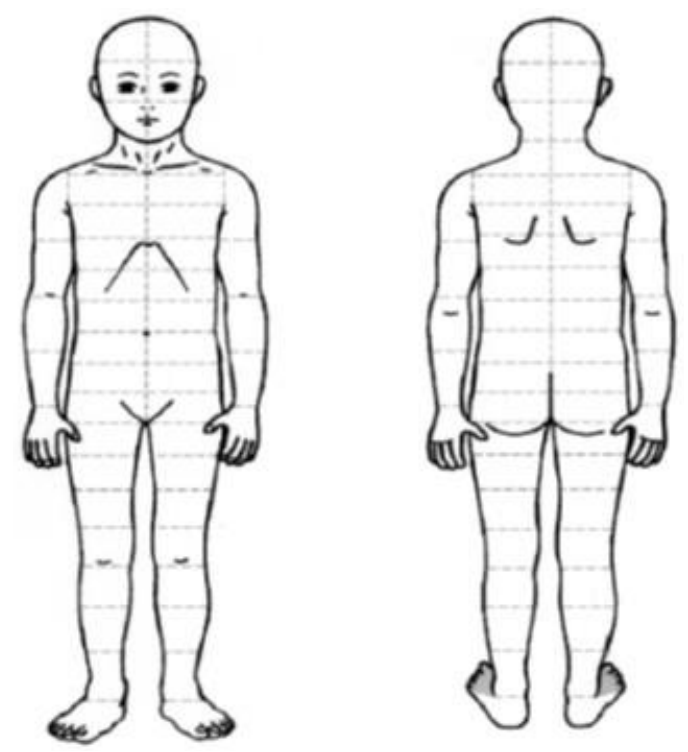

Figure 2. Form to calculate the percentage of body surface area (BSA) with skin lesions.

\subsection{Resting Energy Expenditure Measured by Indirect Calorimetry}

The calorimeter uses the amount of inspired and expired gas exchanges to calculate energy expenditure [21]. The canopy system was used during the test with no compression mask in order to utilize a light comfortable device with no pressure or contact with the subject's face. The participant was placed in the supine position, was free of physical and psychological stress, and was fasted and awake [22]. To guarantee the quality of measurement, the first 10 minutes (period for stabilization) of each indirect calorimetry test were discarded, and the mean of the last 20 min was used to calculate the REE [23]. The output included the estimation of $24 \mathrm{~h} \mathrm{REE}$ and the corresponding respiratory quotient (RQ).

\subsection{Resting Energy Expenditure Estimated by Predictive Equation}

The Oxford equation [24] was used to define the predicted REE (Table 1). This equation is derived from the Schofield equation [25], which is adapted for tropical countries. For subjects under 17 years of age who presented a H/A below the 3rd centile, age correction was performed [16], using the age at which the current measured height corresponded to the 25th centile of the WHO growth curves [18]. 
Table 1. Resting energy expenditure (REE) predicted by the Oxford equation.

\begin{tabular}{ccc}
\hline Age & $\begin{array}{c}\text { Female } \\
\text { (Kcal/day) }\end{array}$ & $\begin{array}{c}\text { Male } \\
\text { (Kcal/day) }\end{array}$ \\
\hline 3-10 years & $20.1 \times$ Weight +507 & $23.3 \times$ Weight +514 \\
10-18 years & $11.1 \times$ Weight +761 & $18.4 \times$ Weight +581 \\
18-30 years & $13.1 \times$ Weight +558 & $16.0 \times$ Weight +545 \\
30-59 years & $9.74 \times$ Weight +694 & $14.2 \times$ Weight +593 \\
\hline
\end{tabular}

\subsection{Energy and Protein Intake}

To assess dietary energy and protein intake, the subjects were instructed to complete a food record form. An explanatory note was provided in order to advise on how to describe consumed foods and methods of preparation and quantify ingested foods. The software CalcNut [26] containing the Brazilian Table of Food Composition [27] was utilized for intake calculations. The total energy and protein intake in grams $(\mathrm{g})$ and per kilogram $(\mathrm{kg})$ of body weight in $24 \mathrm{~h}$ was calculated.

\subsection{Nitrogen Balance}

For the calculation of nitrogen balance, the predicted equation for burns was adapted (9) to consider the percentage of BSA with second and third degree burns as the percentage of wounded/blistered BSA and infected BSA, respectively. The estimation of urinary urea and urinary urea nitrogen was determined by $24 \mathrm{~h}$ urine collection concomitant to food record completion. Urine analysis was performed by the Kjeldahl method [28]. To ensure the complete collection of urine and prevent forgetfulness, a specific container and reminder label (affixed to their underwear) were provided. The participants received verbal and written guidance regarding the correct collection and storage of urine. They were also advised to record the start and end times of the collection, whether oral or topical medication was used on the day of the collection (record of name and quantity), and whether there were any problems during the collection. For the collection, the first morning urine was discarded, and all other urine during the day, including the first morning urine of the following day, were collected. All collections were on Sundays because of the difficulty of collection on the day of class or work. The entire urine collection was checked by the research team.

The following equation was used to calculate nitrogen balance (NB):

$$
\begin{gathered}
\mathrm{NB}(\mathrm{g})=(\text { protein intake } 24 \mathrm{~h}(\mathrm{~g}) / 6.25)-\{\mathrm{UUN}(\mathrm{g} / 24 \mathrm{~h})+4[(0.2 \mathrm{~g} \times \% \text { BSA infected })+ \\
(0.1 \mathrm{~g} \times \% \text { BSA wounded/blistered })]\}
\end{gathered}
$$

where UUN is urinary urea nitrogen.

The subjects who presented negative results of nitrogen balance were considered to be experiencing protein catabolism, and those with positive values were considered to be experiencing protein anabolism. The subjects whose results of the equation were between -1 and +1 were considered to be nitrogen equilibrium.

\subsection{Data Analysis}

The results were expressed in absolute values, per $\mathrm{kg} / \mathrm{body}$ weight, or as a percentage for each participant. A plot of measured REE/predicted REE difference (Y-axis) for each equation against the mean of the measured REE and the predicted REE (X-axis) was created to assess the agreement between indirect calorimetry and prediction equation following the Bland-Altman method [29].

\section{Results}

Ten people (seven females) with RDEB were evaluated, with ages ranging from 4 to 33 years. The sociodemographic characteristics, growth data, and nutritional status are presented in Table 2. All subjects presented with malnutrition, which was characterized by a BMI below the recommended 
values. Three of the six subjects under 17 years had a H/A below the 1st centile, two were between the 1 st and the 3 rd percentile, and one between the 3 and the 5 th percentiles. The difference between the chronological and corrected age ranged from 1 year and 4 months to 5 years and 6 months. All subjects were orally fed, and only one (subject \#7) did not use a high energy/protein supplement.

Table 2. Sociodemographic characteristics, growth, and nutritional status of subjects with recessive dystrophic epidermolysis bullosa.

\begin{tabular}{ccccccc}
\hline Patient & Gender & Age & Corrected Age * & $\begin{array}{c}\text { H/A } \\
\text { (Percentile) }\end{array}$ & $\begin{array}{c}\text { BMI } \\
\mathbf{( k g / \mathbf { m } ^ { 2 } )}\end{array}$ & $\begin{array}{c}\text { Nutritional } \\
\text { Status }\end{array}$ \\
\hline 1 & $\mathrm{~F}$ & $4 \mathrm{y} 8 \mathrm{~m}$ & $3 \mathrm{y} 3 \mathrm{~m}$ & $1-3^{\circ}$ & 11.9 & severe thinness \\
2 & $\mathrm{~F}$ & $7 \mathrm{y} 7 \mathrm{~m}$ & $6 \mathrm{y} 3 \mathrm{~m}$ & $1-3^{\circ}$ & 12.0 & thinness \\
3 & $\mathrm{M}$ & $12 \mathrm{y} 11 \mathrm{~m}$ & $7 \mathrm{y} 11 \mathrm{~m}$ & $<1^{\circ}$ & 13.4 & thinness \\
4 & $\mathrm{~F}$ & $13 \mathrm{y}$ & $9 \mathrm{y} 9 \mathrm{~m}$ & $<1^{\circ}$ & 14.5 & thinness \\
5 & $\mathrm{~F}$ & $16 \mathrm{y} 7 \mathrm{~m}$ & $11 \mathrm{y} 1 \mathrm{~m}$ & $<1^{\circ}$ & 10.3 & severe thinness \\
6 & $\mathrm{~F}$ & $16 \mathrm{y} 7 \mathrm{~m}$ & $12 \mathrm{y} 10 \mathrm{~m}$ & $3-5^{\circ}$ & 12.9 & severe thinness \\
7 & $\mathrm{M}$ & $21 \mathrm{y}$ & $\mathrm{NA}$ & $\mathrm{NA}$ & 17.6 & thinness \\
8 & $\mathrm{~F}$ & $22 \mathrm{y}$ & $\mathrm{NA}$ & $\mathrm{NA}$ & 16.7 & severe thinness \\
9 & $\mathrm{M}$ & $23 \mathrm{y}$ & NA & NA & 12.2 & severe thinness \\
10 & $\mathrm{~F}$ & $33 \mathrm{y}$ & NA & NA & 17.5 & thinness \\
\hline
\end{tabular}

BMI: body mass index; M: male; F: female; y: years, m: months; NA: not applicable; * age correction considering age at the current height at $\mathrm{p} 25$ of the WHO growth curves; ${ }^{* *}$ thinness: $\leq 17$ years with BMI: $1-3^{\circ}$ and adult with BMI: $17-18.4 \mathrm{~kg} / \mathrm{m}^{2}$; severe thinness: $\leq 17$ years with $\mathrm{BMI}<1^{\circ}$ and adult with $\mathrm{BMI}<17 \mathrm{~kg} / \mathrm{m}^{2}$.

Table 3 shows the results of measured and predicted REE as well as nitrogen balance. The REE values predicted by the equation were consistently lower than the values measured, except for two adolescents (subjects \#5 and \#6). The agreement between the predicted equation and indirect calorimetry is detailed in Figure 3. There was poor agreement between the measured and the predicted REE. The Oxford equation underestimated the REE by a mean of 152.4 kcal (limits of agreement: 127.1 and $-431.9 \mathrm{kcal})$.

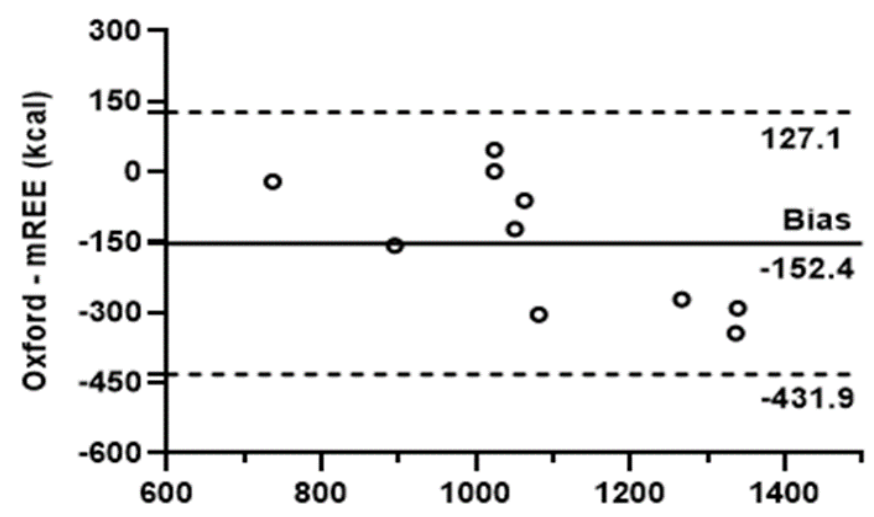

Average of Oxford and mREE (kcal)

Figure 3. Agreement between the Oxford predictive equation and indirect calorimetry of subjects with $\operatorname{RDEB}(n=10)$. m-REE: measured energy expenditure. 
Table 3. Measured and predicted resting energy expenditure, energy intake, nitrogen balance, and their components in subjects with RDEB.

\begin{tabular}{|c|c|c|c|c|c|c|c|c|c|c|c|c|c|c|c|}
\hline \multirow[b]{2}{*}{ Patient } & \multirow[b]{2}{*}{ Gender } & \multirow{2}{*}{$\begin{array}{l}\text { Corrected } \\
\text { Age * }\end{array}$} & \multirow{2}{*}{$\begin{array}{l}\% \text { BSA with } \\
\text { Non-Infected } \\
\text { Lesions }\end{array}$} & \multirow{2}{*}{$\begin{array}{l}\text { \% BSA with } \\
\text { Infected } \\
\text { Lesions }\end{array}$} & \multirow[b]{2}{*}{$\begin{array}{l}\text { Respiratory } \\
\text { Quotient }\end{array}$} & \multicolumn{2}{|c|}{ REE Predicted ${ }^{* *}$} & \multicolumn{2}{|c|}{ REE Measured by IC } & \multirow{2}{*}{$\begin{array}{l}\text { Energy } \\
\text { Intake } \\
\text { (kcal/kg) }\end{array}$} & \multicolumn{2}{|c|}{ Protein Intake } & \multirow{2}{*}{$\begin{array}{l}\text { Urinary Urea } \\
\text { Nitrogen } \\
\text { (g/day) }\end{array}$} & \multirow[b]{2}{*}{$\begin{array}{c}\text { Nitrogen } \\
\text { Balance (g) }\end{array}$} & \multirow{2}{*}{$\begin{array}{c}\text { Nitrogen } \\
\text { Balance } \\
\text { Conclusion }\end{array}$} \\
\hline & & & & & & kcal/day & $\mathrm{kcal} / \mathrm{kg}$ & kcal/day & kcal/kg & & g & $\begin{array}{c}\text { g/kg Body } \\
\text { Weight }\end{array}$ & & & \\
\hline 1 & $\mathrm{~F}$ & 3 y $3 \mathrm{~m}$ & 15 & 0 & 0.89 & 726 & 67 & 747 & 68 & 75 & 44 & 4.01 & 2.91 & -1.91 & catabolic \\
\hline 2 & $\mathrm{~F}$ & 6 y $3 \mathrm{~m}$ & 13 & 3 & 0.82 & 816 & 53 & 973 & 63 & 95 & 81 & 5.24 & 2.78 & -2.52 & catabolic \\
\hline 3 & $\mathrm{M}$ & 7 y $11 \mathrm{~m}$ & 20 & 0 & 0.89 & 989 & 48 & 1111 & 54 & 130 & 85 & 4.18 & 3.42 & 2.23 & anabolic \\
\hline 4 & F & 9 y $9 \mathrm{~m}$ & 22 & 0 & 0.90 & 1032 & 39 & 1093 & 42 & 135 & 138 & 5.27 & 5.17 & 8.05 & anabolic \\
\hline $5^{\mathrm{a}}$ & $\mathrm{F}$ & 11 y $1 \mathrm{~m}$ & 20 & 0 & 0.82 & 1047 & 41 & 1000 & 39 & 130 & 149 & 5.79 & NA & NA & NA \\
\hline 6 & $\mathrm{~F}$ & 12 y $10 \mathrm{~m}$ & 27 & 0 & 0.82 & 1024 & 43 & 1023 & 43 & 57 & 29 & 1.22 & 3.27 & -9.42 & catabolic \\
\hline 7 & $\mathrm{M}$ & $21 \mathrm{y}$ & 17 & 0 & 0.96 & 1164 & 30 & 1508 & 39 & 45 & 59 & 1.49 & 1.83 & 0.62 & balance \\
\hline 8 & $\mathrm{~F}$ & $22 \mathrm{y}$ & 28 & 4 & 0.93 & 1193 & 25 & 1484 & 31 & 59 & 109 & 2.25 & 8.63 & -5.57 & catabolic \\
\hline $9^{b}$ & M & $23 \mathrm{y}$ & 0 & 16 & 0.89 & 929 & 39 & 1233 & 51 & 74 & 99 & 4.12 & 4.71 & -1.70 & catabolic \\
\hline 10 & $\mathrm{~F}$ & $33 \mathrm{y}$ & 23 & 7 & 0.83 & 1130 & 25 & 1402 & 31 & 43 & 70 & 1.56 & 4.68 & -8.27 & catabolic \\
\hline
\end{tabular}

REE: resting energy expenditure; y: years; m: months; kcal: kilocalories, kg: kilo; IC: indirect calorimetry; \% BSA: body surface area; NA: not applicable; ${ }^{a}$ patient with nephropathy;

${ }^{b}$ wheelchair user; ${ }^{*}$ age correction considering age at the current height at $\mathrm{p} 25$ of the WHO growth curves; ${ }^{* *}$ Oxford equation for males $10-18$ years: $18.4 \mathrm{~W}+581 ; 18-30$ years: $16.0 \mathrm{~W}+54$; females $3-10$ years: $20.1 \mathrm{~W}+507 ; 10-18$ years: $11.1 \mathrm{~W}+761 ; 18-30$ years: $13.1 \mathrm{~W}+558 ; 30-59$ years: $9.74 \mathrm{~W}+694$; $\mathrm{W}=$ weight. 
Regarding the nitrogen balance results, it was not possible to evaluate subject \#5 because of the subject's known nephropathy. All subjects had a high protein intake, with six subjects having an intake higher than $4 \mathrm{~g}$ protein $/ \mathrm{kgW}$. Even with their high protein intake, six subjects, with the greatest $\%$ BSA lesions, were catabolic (negative nitrogen balance). All subjects with infected skin lesions were catabolic.

The energy intake ranged from $43 \mathrm{kcal} / \mathrm{kgW}$ to $135 \mathrm{kcal} / \mathrm{kgW}$. All subjects consumed more energy than recommended for their age and gender population. The two subjects with the highest energy consumption per kilogram of weight were anabolic.

\section{Discussion}

This is the first study to evaluate both the measured REE and the nitrogen balance in a group of people with a severe type of EB. Serious nutritional compromise was observed as well as increased energy demand and protein catabolism, which were consistent with the severity of the disease in terms of BSA with skin lesions. These results reinforce the importance of clinical and nutritional management for these patients.

The analysis of the obtained REE data suggests that the Oxford equation is not adapted enough for predicting REE in people with EB, since only two cases had no underestimation of the predicted values. The Bland-Altman plot from the equation and calorimetry showed negative and highly heterogeneous values of measured REE and predicted REE, reflecting the fact that patients with RDEB have increased REE. Our results are consistent with those observed in studies with burns, which identified that the predictive equations underestimate the REE. In a study focusing on subjects with burns [23], the comparison of values measured by indirect calorimetry and predictive equations, as reported by Schofield [25], Harris and Benedict [30], and Food and Agriculture Organization/World Health Organization [31], revealed that in both sexes and in all age ranges, the values resulting from the three equations were lower than the measured ones. Focusing from this same perspective, the experts reported that patients with the most severe types of EB present an increased energy expenditure according to their clinical conditions, on the basis of their clinical practice $[14,15,32,33]$. Lechner-Gruskay et al. [7] evaluated the REE by indirect calorimetry in two children with RDEB and one with JEB. In all cases, the REE obtained by the predicted equation underestimated the measured REE, which agrees with the results for most subjects in the present study.

The predictive equations for REE may be accurate if the difference between the predicted and the measured results is less than 10\% [34]. For adult subjects, all cases were above this limit. In a case report, Bonada et al. [17] observed that the REE estimated by the Harris-Benedict equation $(30.2 \mathrm{kcal} / \mathrm{kgW})$ underestimated the REE measured by calorimetry $(57 \mathrm{kcal} / \mathrm{kgW})$. In our subjects, the measured REE varied from approximately 30 to $50 \mathrm{kcal} / \mathrm{kgW}$, and this variation may be due to differences in $\%$ BSA with lesions. For example, the subject with the highest REE measured by calorimetry (subject \#9) was the one with the highest \% BSA with infected lesions (16\%). The report by Bonada et al. [17] contains no data about the size of the lesions. It is worth mentioning that the excessive energy expenditure in patients with EB reflects the inflammatory and catabolic state and greater heat production necessary to maintain body temperature because of the presence of open wounds [6].

In our study, the RQ ranged from 0.82 to 0.96 . Some calorimeters only measure oxygen consumption and carbon dioxide production to calculate the energy expenditure, assuming that the RQ is a fixed value ( 0.8 or 0.85 ). In our study, the results of $R Q$ validated the performed tests, since the quotients were between 0.67 and 1.3 , which are within physiological values [21,35].

The nutritional recommendations proposed by the Institute of Medicine [31] established that the additional energy required to allow tissue deposition at a suitable rate for health is $20-25 \mathrm{kcal} /$ day for boys and girls from 3 to 18 years of age. The majority of our subjects had a high energy intake. However, only children who consumed around $130 \mathrm{kcal} / \mathrm{kgW}$ were in an anabolic state. Considering that people with RDEB are underweight and require a greater supply of energy [4,14], a deficit of more 
than $15 \%$ of predicted REE, such as that observed in $50 \%$ of this sample, may lead to an underestimation of the nutritional needs, especially for children under stress conditions [36].

Nitrogen balance is an accurate indicator of metabolic stress [37], and it is expected that in healthy people with adequate protein consumption, nitrogen balance will have a zero value [38]. The technique requires the quantification of all nitrogen intake and loss routes [38]. In the case of EB, an estimation of protein loss through the skin is essential for more accurately determining the balance value [9]. In a pioneering study about the metabolic profile in people with EB, Lechner-Gruskay et al. [7] suggested that, despite the lack of information about the measurement of cutaneous protein loss, it is still important to consider this in future studies, since it is quite difficult to maintain a positive balance. In our study, we found that six of the nine subjects evaluated were catabolic. Consequently, it is presumable that the protein requirements of people with EB are significantly higher than those of the healthy population because of the substantial loss of protein through blisters and increased protein synthesis for tissue repair and inflammatory processes [15]. Those subjects with a protein intake of $4-5 \mathrm{~g} / \mathrm{kgW}$ presented lower protein catabolism or were in equilibrium. This may indicate that even with the presence of large BSA with skin lesions, it is possible to attenuate protein catabolism with a high protein intake. The experts suggest that the protein intake should be up to $200 \%$ of the recommended intake in order to improve the nutritional status of children with EB $[14,39]$.

Some limitations of this research need to be identified. First, the small number of subjects and the limited age range due to the rarity of the disease did not allow a robust statistical approach. Second, an analysis of the usual food intake was not performed, which made it difficult to control for possible confounding factors. It was not possible to assess the adequacy of energy consumption because of the lack of specific reference values. However, it was identified that the subjects consumed more energy than recommended for the general population. Finally, the cross-sectional design of the study prevented the evaluation of causality between the variables. Further studies are needed to evaluate the impact of \% BSA with skin lesions, infected or not, on the metabolism of children and adults with EB. Furthermore, there should be intervention studies performed to investigate the effect of diet on the clinical manifestations of the disease.

It was possible to observe that REE was generally underestimated by the predictive equation, and although the subjects had a high protein intake, most of them were catabolic, which was consistent with the presented size of BSA with lesions. Nitrogen balance assessment can be performed in most healthcare settings around the world. In services where a calorimeter is not available, the recommendation of $100-150 \%[4,14]$ of energy requirements is a safe alternative for people at nutritional risk and with the most severe types of the disease. Given the scarcity of studies of this serious disease, our results highlight the importance of routinely evaluating the energy and protein metabolism of patients with RDEB to ensure a better nutritional status.

Author Contributions: Conceptualization, A.P.Z., E.D., and K.d.C.; methodology, A.P.Z.; formal analysis, A.P.Z., R.J. and C.T.; investigation, A.P.Z. and C.T.; data curation A.P.Z., E.D., and K.d.C.; writing-original draft preparation, A.P.Z.; writing - review and editing, C.T., R.J., E.D., and K.d.C.; supervision, K.d.C. and E.D.; project administration, A.P.Z.; funding acquisition, A.P.Z. and C.T.; final review with significant contribution in her area of expertise, R.J.; All authors read and approved the final manuscript.

Funding: This study was financed in part by the Coordenação de Aperfeiçoamento de Pessoal de Nível Superior-Brasil (CAPES)_Finance Code 001.

Acknowledgments: The authors thank all the members of the Clinical Laboratory of the Hospital Universitário de Brasília for their kind support.

Conflicts of Interest: The authors declare no conflict of interest. The funders had no role in the design of the study; in the collection, analyses, or interpretation of data; in the writing of the manuscript, or in the decision to publish the results.

\section{References}

1. Intong, L.R.A.; Murrell, D.F. Inherited epidermolysis bullosa: New diagnostic criteria and classification. Clin. Dermatol. 2012, 30, 70-77. [CrossRef] [PubMed] 
2. Fine, J.D.; Johnson, L.B.; Weiner, M.; Suchindran, C. Gastrointestinal complications of inherited epidermolysis bullosa: Cumulative experience of the National Epidermolysis Bullosa Registry. J. Pediatr. Gastroenterol. Nutr. 2008, 46, 147-158. [CrossRef] [PubMed]

3. Fine, J.-D.; Bruckner-Tuderman, L.; Eady, R.A.; Bauer, E.A.; Bauer, J.W.; Has, C.; Heagerty, A.; Hintner, H.; Hovnanian, A.; Jonkman, M.F.; et al. Inherited epidermolysis bullosa: Updated recommendations on diagnosis and classification. J. Am. Acad. Dermatol. 2014, 70, 1103-1126. [CrossRef] [PubMed]

4. Haynes, L. Nutrition for Children with Epidermolysis Bullosa. Dermatol. Clin. 2010, 28, 289-301. [CrossRef] [PubMed]

5. Zidorio, A.P.C.; Leão, D.O.D.; de Carvalho, K.M.B.; Dutra, E.S. Nutritional outcomes in children with epidermolysis bullosa: Long-term follow-up. Nutr. Hosp. 2018, 35, 265-270. [CrossRef] [PubMed]

6. Fine, J.; Mellerio, J.E. Extracutaneous manifestations and complications of inherited epidermolysis bullosa: Part I. Epithelial associated tissues. J. Am. Acad. Dermatol. 2009, 61, 367-384. [CrossRef] [PubMed]

7. Lechner-Gruskay, D.; Honig, P.J.; Pereira, G.; McKinney, S. Nutritional and Metabolic Profile of Children with Epidermolysis Bullosa. Pediatr. Dermatol. 1988, 5, 22-27. [CrossRef] [PubMed]

8. Lechner-Gruskay, D. Nutritional Assessment of the Child with Junctional and Recessive Distrofic Epidermolysis Bullosa. Master's Thesis, Drextel University, Philadelphia, PA, USA, 1986.

9. Gamelli, R.L. Nutritional problems of the acute and chronic burn patient. Relevance to epidermolysis bullosa. Arch. Dermatol. 1988, 124, 756-759. [CrossRef] [PubMed]

10. Jeschke, M.G.; Mlcak, R.P.; Finnerty, C.C.; Norbury, W.B.; Gauglitz, G.G.; A Kulp, G.; Herndon, D.N. Burn size determines the inflammatory and hypermetabolic response. Crit. Care 2007, 11, R90. [CrossRef]

11. Goran, M.I.; Peters, E.J.; Herndon, D.N.; Wolfe, R.R. Total energy expenditure in burned children using the doubly labeled water technique. Am. J. Physiol. Metab. 1990, 259, E576-E585. [CrossRef]

12. Tancheva, D.; Arabadziev, J.; Gergov, G.; Lachev, N.; Todorova, S.; Hristova, A. Comparison of estimated energy requirements in severely burned patients with measurements by using indirect calorimetry. Ann. Burns Fire Disasters 2005, 18, 16. [PubMed]

13. Tayek, J.A.; Blackburn, G.L. Goals of nutritional support in acute infections. Am. J. Med. 1984, 76, 81-90. [CrossRef]

14. Haynes, L. Clinical Practice Guidelines for Nutrition Support in Children with Epidermolysis Bullosa Including Tool to Help Identify Nutritional Compromise (THINC) in EB. 2007. Available online: http: //www.debra.org.uk/uploads/resources/EB_Guidelines_Final_for_web.pdf: (accessed on 13 August 2018).

15. Zidorio, A.P.C.; Dutra, E.S.; Leão, D.O.D.; Costa, I.M.C. Nutritional aspects of children and adolescents with epidermolysis bullosa: Literature review. An. Bras. Dermatol. 2015, 90, 217-223. [CrossRef] [PubMed]

16. Birge, K. Nutrition management of patients with epidermolysis bullosa. J. Am. Diet. Assoc. 1995, 95, 575-579. [CrossRef]

17. Bonada Sanjaume, A.; Azón, A.; Guillén Rey, N.; Llort Baiget, M.; Figueredo, R.; Salas-Salvadó, J. Estado nutricional y gasto energético en paciente con epidermiólisis ampollosa hereditaria distrófica. Nutr. Hosp. 2004, 19, 58.

18. WHO Multicentre Growth Reference Study Group. WHO Child Growth Standards: Length/Height-for-Age, Weight-for-Age, Weight-for-Length, Weight-for-Height and Body Mass Index-for-Age: Methods and Developments; World Health Organization: Geneva, Switzerland, 2006.

19. World Health Organization. Physical status: The use and interpretation of anthropometry. Report of a WHO Expert Committee. In WHO Technical Report Series; No. 854; WHO: Geneva, Switzerland, 1995.

20. Ministério da Saúde. Secretaria de Atenção à Saúde. Departamento de Atenção Básica. Orientações Para A Coleta e Análise de Dados Antropométricos Em Serviços de Saúde: Norma Técnica do SISTEMA de Vigilância Alimentar e Nutricional—Sisvan. Brasília. 2011. Available online: http://200.17.213.49/lib/exe/ fetch.php/projetos:obesidade:sisvannormatecnica.pdf (accessed on 19 August 2018).

21. Oshima, T.; Berger, M.M.; De Waele, E.; Guttormsen, A.B.; Heidegger, C.-P.; Hiesmayr, M.; Singer, P.; Wernerman, J.; Pichard, C. Indirect calorimetry in nutritional therapy. A position paper by the ICALIC study group. Clin. Nutr. 2017, 36, 651-662. [CrossRef]

22. Haugen, H.A.; Chan, L.-N.; Li, F. Indirect calorimetry: A practical guide for clinicians. Nutr. Clin. Pract. 2007, 22, 377-388. [CrossRef] 
23. Suman, O.E.; Mlcak, R.P.; Chinkes, D.L.; Herndon, D.N. Resting energy expenditure in severely burned children: Analysis of agreement between indirect calorimetry and prediction equations using the Bland-Altman method. Burns 2006, 32, 335-342. [CrossRef]

24. Henry, C.J.K. Basal metabolic rate studies in humans: Measurement and development of new equations. Public Health Nutr. 2005, 8, 1133-1152. [CrossRef]

25. Schofield, W.N. Predicting basal metabolic rate, new standards and review of previous work. Hum. Nutr. Clin. Nutr. 1985, 39, 5-41.

26. Costa, T.H.M. CalcNut: Plataforma Para Cálculo de Dieta. Departamento de Nutrição, Faculdade de Ciências da Saúde, Universidade de Brasília. Available online: https://fs.unb.br/nutricao/calcnut/?page_id=47 (accessed on 31 August 2018).

27. Universidade Estadual de Campinas-UNICAMP. Tabela Brasileira de Composição de Alimentos-TACO. 4. ed. rev. e ampl; UNICAMP/NEPA: Campinas, Brazil, 2011; p. 161. Available online: http://www.unicamp.br/ nepa/taco/tabela.php?ativo=tabela (accessed on 10 September 2018).

28. Jacobs, S.C. Assessment of automated nitrogen analysis of biological fluids with reference to the Kjeldahl method. J. Clin. Pathol. 1968, 21, 218-219. [CrossRef] [PubMed]

29. Bland, J.M.; Altman, D. Statistical methods for assessing agreement between two methods of clinical measurement. Lancet 1986, 327, 307-310. [CrossRef]

30. Harris, J.A.; Benedict, F.G. A biometric study of human basal metabolism. Proc. Natl. Acad. Sci. USA 1918, 4, 370-373. [CrossRef] [PubMed]

31. Institute of Medicine; National Research Council. Dietary Reference Intakes for Energy, Carbohydrate, Fiber, Fat, Fatty Acids, Cholesterol, Protein and Amino Acids (Macronutrients); National Academy Press: Washington, DC, USA, 2005. Available online: http://www.nap.edu/catalog/10490 (accessed on 16 March 2018).

32. Fedeles, F.; Murphy, M.; Rothe, M.J.; Grant-Kels, J.M. Nutrition and bullous skin diseases. Clin. Dermatol. 2010, 28, 627-643. [CrossRef] [PubMed]

33. Bello, Y.M.; Falabella, A.F.; Schachner, L.A. Management of epidermolysis bullosa in infants and children. Clin. Dermatol. 2003, 21, 278-282. [CrossRef]

34. Jotterand Chaparro, C.; Moullet, C.; Taffé, P.; Laure Depeyre, J.; Perez, M.; Longchamp, D.; Cotting, J. Estimation of Resting Energy Expenditure Using Predictive Equations in Critically Ill Children: Results of a Systematic Review. J. Parenter. Enter. Nutr. 2018, 42, 976-986. [CrossRef]

35. Mc Clave, S.A.; Lowen, C.C.; Kleber, M.J.; McConnell, J.W.; Jung, L.Y.; Goldsmith, L.J. Clinical use of the respiratory quotient obtained from indirect calorimetry. J. Parenter. Enter. Nutr. 2003, 27, 21-26. [CrossRef]

36. De Cosmi, V.; Milani, G.P.; Mazzocchi, A.; D’Oria, V.; Silano, M.; Calderini, E.; Agostoni, C.; D’Oria, V. The metabolic response to stress and infection in critically ill children: The opportunity of an individualized approach. Nutrients 2017, 9, 1032. [CrossRef]

37. Dickerson, R.N. Using nitrogen balance in clinical practice. Hosp. Pharm. 2005, 40, 1081-1087. [CrossRef]

38. World Health Organization. Protein and amino acid requirements in human nutrition. In WHO Technical Report Series; World Health Organization: Geneva, Switzerland, 2002; p. 935.

39. Colomb, V.; Bourdon-Lannoy, E.; Lambe, C.; Sauvat, F.; Hadj-Rabia, S.; Teillac, D.; De Prost, Y.; Bodemer, C.; Bourdon-Lannoy, E. Nutritional outcome in children with severe generalized recessive dystrophic epidermolysis bullosa: A short-and long-term evaluation of gastrostomy and enteral feeding. Br. J. Dermatol. 2012, 166, 354-361. [CrossRef]

(C) 2019 by the authors. Licensee MDPI, Basel, Switzerland. This article is an open access article distributed under the terms and conditions of the Creative Commons Attribution (CC BY) license (http://creativecommons.org/licenses/by/4.0/). 